NBER WORKING PAPER SERIES

\title{
REVENUE AND INCENTIVE EFFECTS OF BASIS STEP-UP AT DEATH: LESSONS FROM THE 2010 "VOLUNTARY" ESTATE TAX REGIME
}

\author{
Robert Gordon \\ David Joulfaian \\ James Poterba \\ Working Paper 22090 \\ http://www.nber.org/papers/w22090 \\ NATIONAL BUREAU OF ECONOMIC RESEARCH \\ 1050 Massachusetts Avenue \\ Cambridge, MA 02138 \\ March 2016
}

James Poterba is the Mitsui Professor of Economics at the Massachusetts Institute of Technology and the President and CEO of the National Bureau of Economic Research. He is also a Trustee of the College Retirement Equity Fund (CREF) and the TIAA-CREF Mutual Funds, financial institutions that offer retirement-oriented products. A full listing of companies and institutions from which he has received honorarium payments of more than $\$ 500$ in the past three years may be found at: http://economics.mit.edu/faculty/poterba/outside. The views expressed herein are those of the authors and do not necessarily reflect the views of the National Bureau of Economic Research. Robert Gordon is an Adjunct Professor at the Stern School of Business at New York University and the President of Twenty-First Securities. Twenty-First is a brokerage and financial advice firm that serves high net worth clients and provides tax and investment advice. Some clients could be subject to estate and capital gains taxes, and could be affected by policy changes related to these taxes.

At least one co-author has disclosed a financial relationship of potential relevance for this research. Further information is available online at http://www.nber.org/papers/w22090.ack

NBER working papers are circulated for discussion and comment purposes. They have not been peer-reviewed or been subject to the review by the NBER Board of Directors that accompanies official NBER publications.

(C) 2016 by Robert Gordon, David Joulfaian, and James Poterba. All rights reserved. Short sections of text, not to exceed two paragraphs, may be quoted without explicit permission provided that full credit, including $\odot$ notice, is given to the source. 
Revenue and Incentive Effects of Basis Step-Up at Death: Lessons from the 2010 "Voluntary" Estate Tax Regime

Robert Gordon, David Joulfaian, and James Poterba

NBER Working Paper No. 22090

March 2016

JEL No. H24

\section{ABSTRACT}

In 2010, the U.S. estate tax expired and executors of wealthy decedents were not required to file estate tax returns. In the absence of the estate tax, beneficiaries received assets with carryover rather than stepped-up basis. Unrealized capital gains accounted for 44 percent of the fair market value of non-cash assets in estates that chose the carryover basis regime, and an even higher percentage for some asset categories. Many of the largest gains were on assets that had been held for at least two decades.

Robert Gordon

Twenty-first Securities

780 Third Avenue

New York, NY 10017

and NYU Stern School of Business

bob@twenty-first.com

David Joulfaian

Department of the Treasury

1500 Pennsylvania Avenue, NW

Washington, DC 20220

and Department of Economics

Georgetown University

david.joulfaian@treasury.gov
James Poterba

Department of Economics, E52-444

MIT

77 Massachusetts Avenue

Cambridge, MA 02139

and NBER

poterba@nber.org 


\title{
Revenue and Incentive Effects of Basis Step-Up at Death: Lessons from the 2010 "Voluntary" Estate Tax Regime
}

\author{
Robert Gordon, David Joulfaian, and James Poterba ${ }^{*}$
}

The effective tax burden on the returns from long-term investments held by many highnet-worth households in the United States is determined in significant part by the interaction between the income tax treatment of capital gains and the estate tax, in particular the tax provision that allows basis step-up for assets that are passed to beneficiaries at death.

To illustrate the importance of basis step-up, consider a zero-basis asset on which an investor accrues a one dollar capital gain at time zero. Assume that the future expected return each period on this asset is $r$, that the investor applies the same discount rate $r$ to future capital gains tax liabilities, and that in all future periods the investor has a probability p of needing to sell the asset and a probability q of dying. Ignore the possibility that the asset may decline in value, which would raise issues of loss-harvesting for tax purposes and complicate the analysis of the effective tax burden.

If the investor has not yet sold the asset and dies after k periods, the asset passes to his beneficiaries, who will sell the asset upon receipt. With basis step-up, the tax basis for the beneficiaries is $(1+r)^{k}$. Since this is also the market value at the time of sale, there is no capital gains tax liability when heirs sell the asset. The probability that capital gains taxes are ever collected on the initial one dollar gain is $\mathrm{p} /(\mathrm{p}+\mathrm{q})$, and the probability that the gains are not taxed as a result of basis step-up is $\mathrm{q} /(\mathrm{p}+\mathrm{q})$. The expected present discounted value of the capital gains tax liability on the initial gain is

\footnotetext{
*Gordon: Stern School of Business, New York University, and Twenty-First Securities, 780 Third Avenue, New York, NY 10017 (bob@twenty-first.com); Joulfaian: Office of Tax Analysis, U.S. Department of the Treasury, 1500 Pennsylvania Avenue NW, Washington DC 20220 and Department of Economics, Georgetown University (david.joulfaian@treasury.gov); Poterba: MIT and NBER, 77 Massachusetts Avenue Room E52-444, Cambridge MA 02139 (poterba@mit.edu). We thank Danny Yagan for helpful comments.
} 


$$
\begin{aligned}
P D V \text { CG Tax }= & \sum_{j=1}^{\infty} p *(1-p-q)^{j-1} *\left\{\tau *(1+r)^{j-1}\right\} /(1+r)^{j-1} \\
& =\tau p * \sum_{j=0}^{\infty}(1-p-q)^{j}=\frac{\tau p}{p+q}
\end{aligned}
$$

In the absence of basis step-up at death, the expected present value of the capital gains tax liability would be $\tau$, the same as if the gain was realized when it accrued, because the asset and the gain is assumed to rise in value at the investor's discount rate.

The effect of basis step-up on effective capital gains tax burdens has attracted research attention for decades. Martin J. Bailey (1969) compared capital gain realizations reported on tax returns with an estimate of accruing stock gains for individuals over the 1926-1961 period. He inferred that more than two-thirds of individuals’ gains on corporate stock were not taxed because the stocks were passed at death, which implies $\mathrm{p} /(\mathrm{p}+\mathrm{q})<1 / 3$.

More recent research has tried to estimate unrealized gains as a fraction of the fair market value of the assets that are bequeathed each year, a ratio that is provides information on the revenue impact of basis step-up but does not bear directly on $\mathrm{p} /(\mathrm{p}+\mathrm{q})$. Poterba and Scott Weisbenner (2001) used data from the 1998 Survey of Consumer Finances that included estimates of the current market value of asset holdings and the purchase price of these assets, along with estimates of the one-year mortality rates for survey respondents, to estimate unrealized gains as a share of the market value of assets held by potential decedents who might be subject to the estate tax. Their results suggested that unrealized gains would represent about one third of the gross market value of assets that were included in taxable estates. Robert Avery, Daniel Grodzicki, and Kevin Moore (2013) applied a similar algorithm to data from the 2010 Survey of Consumer Finances. They found unrealized gains as a share of market value of about 
one third for estates with total values close to the estate tax threshold, i.e. between $\$ 5$ and $\$ 10$ million. Gains represented more than half of the value of estates worth more than $\$ 100$ million. The effective capital gains tax rate cannot be inferred from the fraction of an estate's value that consists of unrealized appreciation. In the simple example above, the entire value of the asset passing at death would be unrealized gain, but without information on $\mathrm{p}$, the probability of an asset sale in each year, it would not be possible to compute the present discounted value of the capital gains tax burden on the appreciated asset. Looking only at the asset composition of estates ignores the capital gain realizations that take place prior to death and that are reported on income tax returns. Nevertheless, if gains accrue each year and the annual probability of forced liquidation is high, unrealized gains will represent a smaller fraction of the fair market value of assets passed at death than if the probability $\mathrm{p}$ is low. Low values of gains relative to estate market value imply that $\mathrm{p} /(\mathrm{p}+\mathrm{q})$ is close to one and that the present value of capital gains taxes on an appreciating asset is close to $\tau$. A high value of unrealized gains relative to estate value suggests a low value of $\mathrm{p} /(\mathrm{p}+\mathrm{q})$.

\section{The 2010 "Voluntary" Estate Tax}

The temporary expiration of the estate tax and associated basis carry-over regime in 2010 provides a unique opportunity to explore the importance of unrealized capital gains in estates. The Economic Growth and Tax Reform Reconciliation Act of 2001 included a set of rising thresholds for estate tax liability between 2001 and 2009, and a one-year estate tax repeal effective January 1, 2010. Most tax policy analysts and tax planners expected the estate tax to be re-instituted prior to this date, but it was not. For 2010, the estate tax was replaced by a basis carryover regime, in which assets transferred to heirs retained the decedent's tax basis. 
The Tax Relief, Unemployment Insurance Reauthorization, and Job Creation Act of 2010, which was became law in December 2010, reinstated the estate tax retroactively effective January 1, 2010. For estates of 2010 decedents, however, the estate tax was voluntary. While the default was for executors of such estates to file estate tax returns, and to receive basis step-up on assets passed to beneficiaries, executors could also choose not pay estate tax, and to carry over the basis of the decedent's assets to beneficiaries. For some estates, the estate tax liability was less than the present discounted value of the capital gains tax liability associated with carryover basis. A number of executors therefore chose to file estate tax returns and to pay estate tax on the estates of 2010 decedents, even though they were not required to do so.

The "voluntary" estate tax regime of 2010 led to sharp changes in estate tax filings. Data from adjacent years demonstrates this. The estate tax filing threshold, the value of the estate plus taxable gifts that triggered estate tax liability, was \$3.5 million in 2009 and \$5 million in 2010 and 2011. Executors filed 7,948 estate tax returns for 2009 decedents with wealth of over $\$ 5$ million. There were 9,285 such filings for 2011 decedents. For 2010 decedents, by comparison, there were 2,788 estate tax returns filed, roughly one third the number of filings for estates worth over $\$ 5$ million in the previous year. The distribution of estate tax returns for 2010 was also quite different from that for 2009. Returns for which the gross estate and gifts were valued at between $\$ 5$ and $\$ 10$ million accounted for about two thirds of the estate tax returns for 2009 decedents, but for over 80 percent of those for 2010 decedents. There were 1,046 estate tax returns with gross value of more than $\$ 20$ million filed for 2009 decedents, 1,206 such returns for 2011 decedents, but only 146 such returns for 2010 decedents.

The more pronounced decline in the number of estate tax filings for decedents with large estates than for those with estates near the filing threshold is consistent with the comparison of 
potential estate and capital gains tax liabilities presented in Gordon, Joulfaian, and Poterba (2015). Because the estate tax for 2010 applied only to the net value of assets in excess of $\$ 5$ million, and because the capital gains tax rate for most beneficiaries would be less than the estate tax rate, for very large estates even with substantial unrealized gains the estate tax was likely to exceed the present value of the capital gains tax liability.

\section{Unrealized Capital Gains and 2010 Estates}

The optional carry-over basis regime of 2010 provides a rich opportunity to learn about the value of unrealized capital gains that are stepped up at death. If executors chose not to pay estate tax, they were required to file Form 8939, which contains information on the fair market value (FMV) of assets in the estate, their basis, and the allocation of the "additional basis" that was permitted under the basis carry-over regime. Some assets, such as cash and cash-equivalent assets and holdings in retirement plans, did not have to be reported on Form 8939. The beneficiaries of any estate that elected carry-over basis were eligible for a $\$ 1.3$ million increase in basis; spousal beneficiaries qualified for an additional \$3 million basis allocation. Thus for a 2010 decedent whose estate was left to his spouse, the basis on assets with up to $\$ 4.3$ million in unrealized gains could be "stepped up" even under the carry-over basis regime.

The Office of Tax Analysis (OTA) (2014) summarizes the information on unrealized gains as a share of market value for a subset of 5,505 Form 8939 filings which had been processed by Internal Revenue Service Statistics of Income (SOI) division by early 2014. OTA (2014) presents detailed tabulations of the value of unrealized gains for decedents in different net worth, age, and gender categories. Our tabulations are similar, but they differ from the OTA (2014) findings because they are based on the full set of Form 8939 filings, 8,047 returns. Executors filed 4,152 Forms 8939 for 2010 decedents for whom the fair market value of gross 
assets in their estate, plus taxable gifts that were reported between 2002 and 2010, exceeded \$5 million. The gross value of the estate, plus gifts, was between $\$ 5$ and $\$ 10$ million for 2,075, or just over half, of these returns. Another 853 returns fell in the \$10-15 million range, 360 were in the \$15-20 million range, and 864 corresponded to estates for which gross assets plus gifts exceeded \$20 million.

Our analysis begins with a sample of 8,047 Form 8939 filings, but the sample is reduced to 7,937 after we drop duplicate returns, typically amended returns, as well as returns rejected by the IRS because they were incomplete, corresponded to the wrong year, or had other filing problems. The Form 8939 filings provide a rich source of information on the basis and the fair market value of assets in estates. The total fair market value (FMV) for the assets on these 7,937 returns was $\$ 96.1$ billion, with corresponding unrealized gains of $\$ 41.8$ billion. The ratio of unrealized gains to FMV, which we label the Unrealized Gain Ratio (UGR), was 0.436. This ratio is somewhat greater than previous estimates. OTA (2014), Poterba and Weisbenner (2001), and Avery, Grodzicki, and Moore (2013) all estimate UGRs of about one-third. If we add all of the assets reported on estate tax returns to those reported on Form 8939 filings, and assume that there were no unrealized gains on these assets, the ratio of unrealized gains to the market value of assets held by decedents would by 33.9 percent.

Aggregate information on the UGR conceals substantial variation across asset classes, likely due both to differences in the underlying rate of asset appreciation and to differences in the likelihood of selling the asset while alive. Table 1 presents information on the UGR for the most widely-held asset categories reported on Form 8939 filings. Not surprisingly, fixed income instruments show very low UGRs, while equities and some real estate categories show much higher values. For state and local bonds, for example, unrealized gains were only 4.3 percent of 
the market value; for federal bonds, the UGR was 1.2 percent. By comparison, for vacant land the UGR was 61.7 percent, for closely held stock it was 72.5 percent, for corporate stock it was 63.1 percent, and for depletable assets and intangibles it was 83.6 percent. Since the value of basis step-up may vary across different asset categories, this tax code provision is likely to have different effects on the effective capital gains tax rates on different assets.

Even within asset classes, there is substantial heterogeneity in UGRs across Forms 8939. Table 2 reports on this variation for three asset classes with high average UGRs: closely held stock, other stock, which is typically publicly traded stock, and real estate. Although the average UGRs for these three asset classes were $0.725,0.631$, and 0.453 , respectively, a substantial number of Form 8939 filings showed losses for each category. For closely held stock, 22 percent of the Form 8939 filings showed losses; for other corporate stock, 19 percent, and for real estate, 21 percent. Losses represented 5.3 percent of the net gains on corporate stock, 1.5 percent of the gains on closely held stocks, and 7.8 percent of the gains on real estate. There were also a substantial number of Form 8939 filings for which gains represented most of the FMV of these asset classes. Forty-two percent of the Form 8939 filings that included closely held stocks reported an unrealized gain of more than 70 percent of the fair market value of this asset position. For corporate stock the analogous value was 20.5 percent, and for real estate it was 29.5 percent. The dispersion of UGRs even within asset classes is an important reminder of the range of possible return outcomes for risky assets. It also suggests the need to consider lossoffset limitations in assessing the effective burden of capital gains taxes.

The basis step-up provisions that apply in tandem with the U.S. estate tax require beneficiaries to value assets at the time of the decedent's death. Losses that accrued during the decedent's lifetime are not passed forward to the beneficiary; there is no "step down" in basis. A 
beneficiary cannot sell assets that are worth less than the decedent's basis and use the resulting losses to offset taxes on other gains. When estimating the revenue consequences of shifting to a carryover basis regime, it is important to recognize the possibility of revenue losses associated with some taxpayers who will be able to pass forward losses that are currently lost at death.

The evidence presented in Bailey's (1969) study of gain realization rates suggested that many of the assets that passed to beneficiaries might have been held for decades by the decedents. The Form 8939 filings provide direct information on this issue. Table 3 presents data on the date of acquisition of closely held stocks, other stocks, and real estate. For each of these asset categories, the executor could not identify the date of purchase for a significant fraction of the reported holdings: 17.1 percent for closely held stocks, 15.4 percent for other stocks, and 11 percent for real estate. Among the positions that could be identified with a purchase date, most of the gains were associated with assets that were held for more than twenty years. For closely held stock, 64.2 percent of all gains, and 85 percent of all gains for which the purchase date was known, corresponded to assets that the decedent held for more than twenty years. For real estate, the analogous values are 49.3 percent and 64.8 percent, respectively. For other corporate stock, only 24.8 percent of all gains correspond to positions that were known to have been purchased more than twenty years ago, but these gains represent 71.9 percent of all gains on stock positions with known start dates. These data are consistent with low realization rates and long holding periods for at least some assets held by high net worth investors.

\section{Conclusions}

The information on the unrealized gains and losses on assets that were included in the estates of decedents who passed away in 2010 provides useful information for estimating the potential revenue cost of basis step-up. To translate this information into a revenue estimate, it 
must be augmented as in OTA (2014) with data on the value of unrealized gains on assets held by decedents who were not required to file estate tax returns, because their estates were valued at more than $\$ 5$ million, but who could still take advantage of basis step-up.

There are two limitations in using the Form 8939 data from 2010 for either revenue estimates or effective tax rate calculations. The first arises from the voluntary nature of the estate tax for 2010 decedents. If executors decided whether to elect the carry-over basis regime or the estate tax-cum-basis step-up regime based on the expected tax liability under the two regimes, then the observed Forms 8939 represent a selected sample from the set of all estates. Gordon, Joulfaian, and Poterba (2015) present evidence that the projected differential in tax liability between the two tax regimes helped predict whether an executor would file an estate tax return or take advantage of the carry-over basis regime. The selection would lead to estates for which the value of basis step-up was smallest filing Form 8939. It is difficult to determine how the reported Form 8939 data should be adjusted to take account of this selection phenomenon. It nevertheless seems likely that the UGR on Form 8939 filings is an under-estimate of the ratio for the entire decedent population, thus underestimating the revenue loss from basis step-up. While our analysis focuses on net gains, some decedents hold assets with substantial losses. Basis stepup erases these losses and potentially increases the capital gains tax liability of the beneficiaries of these decedents.

The second limitation concerns the generalizability of the asset gain and loss positions for 2010. The voluntary estate tax regime occurred two years after the onset of the recent financial crisis. Asset values in some categories, such as real estate and corporate stock, may have been lower in 2010 than in more typical years. 


\section{References}

Avery, Robert B., Daniel Grodzicki, and Kevin B. Moore, 2013. “Estate vs. Capital Gains Taxation: An Evaluation of Prospective Policies for Taxing Wealth at the Time of Death.” Working Paper 2013-28, Federal Reserve Board, Division of Research \& Statistics \& Monetary Affairs, Washington, DC.

Bailey, Martin J. 1969. “Capital Gains and Income Taxation.” In Arnold C. Harberger and Martin J. Bailey, The Taxation of Income from Capital. Washington: Brookings Institution, 11-49.

Gordon, Robert, David Joulfaian, and James Poterba. 2015. “Choosing between the Estate Tax and Basis Carryover Regime of 2010,” mimeo, MIT Economics Department.

Office of Tax Analysis, U.S. Treasury Department. 2014. “Tax Expenditure for Exclusion of Capital Gains at Death.” Memorandum, Washington D.C.

Poterba, James and Scott Weisbenner. 2001. “The Distributional Burden of Taxing Estates and Unrealized Capital Gains at the Time of Death.” In William Gale, James Hines, and Joel Slemrod, Rethinking Estate and Gift Taxation. Washington: Brookings Institution, 216247. 
Table 1: Fair Market Value (FMV) and Basis on Carryover Basis Returns (Form 8939)

\begin{tabular}{|c|c|c|c|c|}
\hline \multirow[b]{2}{*}{ Asset Category } & \multirow[b]{2}{*}{$\begin{array}{l}\text { Number of } \\
\text { Form } 8939 \\
\text { Returns } \\
\text { With Asset } \\
\text { Class }\end{array}$} & \multicolumn{3}{|c|}{ Conditional on Positive Holding } \\
\hline & & Mean FMV (000s) & $\begin{array}{l}\text { Mean } \\
\text { Unrealized } \\
\text { Gains } \\
(000 \mathrm{~s})\end{array}$ & $\begin{array}{l}\text { Unrealized } \\
\text { Gain/ FMV }\end{array}$ \\
\hline All & 7,937 & 12,110 & 5,285 & 0.436 \\
\hline Corporate Stock & 5,998 & 5,333 & 3,365 & 0.631 \\
\hline Personal Residence & 4,314 & 1,004 & 379 & 0.378 \\
\hline Other Assets & 4,107 & 305 & 62 & 0.203 \\
\hline State/Local Bonds & 4,088 & 2,766 & 118 & 0.043 \\
\hline Real Estate (excluding land) & 4,050 & 1,958 & 887 & 0.453 \\
\hline Corporate/Foreign Bonds & 2,368 & 621 & 37 & 0.060 \\
\hline Limited Partnerships & 1,915 & 3,326 & 1,322 & 0.398 \\
\hline Cash & 1,824 & 948 & 61 & 0.064 \\
\hline Real Estate Mutual Funds & 1,577 & 222 & 84 & 0.379 \\
\hline Other Federal Bonds & 1,505 & 1,203 & 14 & 0.012 \\
\hline Mutual Funds & 1,461 & 377 & 29 & 0.077 \\
\hline Vacant Land & 1,397 & 1,006 & 621 & 0.617 \\
\hline Closely Held Stock & 1,297 & 6,912 & 5,011 & 0.725 \\
\hline Other Non-corporate Businesses & 1,253 & 3,580 & 806 & 0.225 \\
\hline Mortgages / Notes & 1,160 & 2,360 & -92 & -0.039 \\
\hline Bond Funds & 1,141 & 242 & 17 & 0.070 \\
\hline Annuities and Retirement Assets & 766 & 1,553 & 821 & 0.529 \\
\hline Farms & 756 & 2,628 & 1,567 & 0.596 \\
\hline Art & 681 & 1,601 & 1,052 & 0.657 \\
\hline Real Estate Partnerships & 628 & 3,817 & 2,066 & 0.541 \\
\hline Hedge Funds / Private Equity & 626 & 1,856 & 131 & 0.071 \\
\hline Depletable / Intangible Assets & 540 & 1,111 & 929 & 0.836 \\
\hline
\end{tabular}

Source: Authors' tabulation using Form 8939 returns filed in for year 2010 decedents. 
Table 2: Distribution of Unrealized Gain Ratios by Asset Class

\begin{tabular}{|l|l|l|}
\hline $\begin{array}{l}\text { Ratio of Gains to } \\
\text { Fair Market Value }\end{array}$ & $\begin{array}{l}\text { Share of } \\
\text { Returns }\end{array}$ & Share of Gains \\
\hline \multicolumn{2}{|l|}{ Closely Held Stock (N = 1297) } \\
\hline G/FMV $<0$ & $22.1 \%$ & $-5.3 \%$ \\
\hline $0<$ G/FMV $<.2$ & 10.6 & 0.8 \\
\hline $0.2<$ G/FMV $<0.4$ & 9.7 & $3.0 \%$ \\
\hline $0.4<$ G/FMV $<0.7$ & 15.7 & $9.0 \%$ \\
\hline G/FMV $>0.7$ & 41.9 & 92.0 \\
\hline Corporate Stock $(\mathrm{N}=5998)$ & \\
\hline G/FMV $<0$ & $19.0 \%$ & $-1.5 \%$ \\
\hline $0<$ G/FMV $<.2$ & 24.7 & 2.1 \\
\hline $0.2<$ G/FMV $<0.4$ & 17.1 & 5.3 \\
\hline $0.4<$ G/FMV $<0.7$ & 18.8 & 14.5 \\
\hline G/FMV $>0.7$ & 20.5 & 79.6 \\
\hline Real Estate & & $-7.8 \%$ \\
\hline G/FMV $<0$ & $20.8 \%$ & 2.7 \\
\hline $0<$ G/FMV $<.2$ & 12.8 & 8.9 \\
\hline $0.2<$ G/FMV $<0.4$ & 13.6 & 35.5 \\
\hline $0.4<$ G/FMV $<0.7$ & 23.3 & 60.7 \\
\hline G/FMV $>0.7$ & 29.5 & 8939 \\
\hline Source: Aund & & \\
\hline
\end{tabular}

Source: Authors' tabulation using Forms 8939 and 706 filings for decedents who died in 2010.

Table 3: Holding Period and Unrealized Gain Ratios (UGR) for Three Asset Classes

\begin{tabular}{|c|c|c|c|c|c|c|c|c|c|}
\hline \multirow{2}{*}{$\begin{array}{l}\text { Holding } \\
\text { Period at } \\
\text { Time of } \\
\text { Death }\end{array}$} & \multicolumn{3}{|c|}{$\begin{array}{l}\text { Closely Held Stock } \\
\text { (2,051 Positions) }\end{array}$} & \multicolumn{3}{|c|}{$\begin{array}{l}\text { Corporate Stock (26,798 } \\
\text { Positions) }\end{array}$} & \multicolumn{3}{|c|}{$\begin{array}{l}\text { Real Estate } \\
\text { (7,408 Positions) }\end{array}$} \\
\hline & $\begin{array}{l}\text { Percent } \\
\text { of } \\
\text { Returns }\end{array}$ & $\begin{array}{l}\text { Percent } \\
\text { of } \\
\text { Gains }\end{array}$ & UGR & $\begin{array}{l}\text { Percent } \\
\text { of } \\
\text { Returns }\end{array}$ & $\begin{array}{l}\text { Percent } \\
\text { of } \\
\text { Gains }\end{array}$ & UGR & $\begin{array}{l}\text { Percent } \\
\text { of } \\
\text { Returns }\end{array}$ & $\begin{array}{l}\text { Percent } \\
\text { of } \\
\text { Gains }\end{array}$ & UGR \\
\hline$<5$ Years & $11.4 \%$ & $0.3 \%$ & $7.1 \%$ & $29.1 \%$ & $2.2 \%$ & $13.2 \%$ & $14.3 \%$ & $-0.2 \%$ & $-0.6 \%$ \\
\hline $5-10$ Years & 12.5 & 4.8 & 38.8 & 18.3 & 2.3 & 35.5 & 13.7 & 5.2 & 18.3 \\
\hline $10-15$ Years & 12.4 & 2.7 & 40.9 & 12.4 & 2.8 & 50.4 & 12.4 & 10.8 & 41.6 \\
\hline $\begin{array}{l}15-20 \\
\text { Years }\end{array}$ & 9.8 & 3.5 & 53.7 & 8.0 & 2.4 & 68.2 & 9.4 & 10.0 & 52.8 \\
\hline$>20$ Years & 36.8 & 64.2 & 84.7 & 16.9 & 24.8 & 88.3 & 39.2 & 49.3 & 72.3 \\
\hline Unknown & 17.1 & 24.5 & 76.0 & 15.4 & 65.5 & 66.1 & 11.1 & 24.9 & 49.3 \\
\hline
\end{tabular}

Source: Authors' tabulations using Form 8939 return filings for 2010. Tabulations for the share of gains are drawn from information on the net gain for each position, so some entries underlying the gain calculation are losses. 